\title{
VEGFA wt Allele
}

National Cancer Institute

\section{Source}

National Cancer Institute. VEGFA wt Allele. NCI Thesaurus. Code C52018.

Human VEGFA wild-type allele is located within $6 \mathrm{p} 12$ and is approximately $16 \mathrm{~kb}$ in length.

This allele, which encodes vascular endothelial growth factor A protein, plays a role in several processes related to vasculature function, including angiogenesis. The allele is also involved in endothelial cell growth cell migration and apoptotic inhibition. 